\title{
Post-socialist Development and Rehabilitation of Large Housing Estates in Central and Eastern Europe: A Review
}

\author{
Dejana NEDUČIN, Marko ŠKORIĆ, Milena KRKLJEŠ
}

\begin{abstract}
In the socialist times, large housing estates in the Central and East European (CEE) cities were praised for effectively resolving the housing crisis, providing good and homogenous housing conditions at reasonable costs and enabling rapid urbanization. Following the collapse of communism, they have met with various consequences of low-cost construction based on prefabrication, lack of repair and upgrading investments and neglected or deferred maintenance, and the Western experience drew attention to the socio-economic outcomes of further physical downgrading. As the flats located in these estates make up almost half of the total urban housing stock in the CEE region, thus having a significant impact on the overall housing quality, this paper discusses the post-socialist context of development of these estates based on the existing literature and an interdisciplinary analytical approach, with an emphasis on their rehabilitation. The research questions relate to the problems they have been affected by, mechanisms and methods of interventions and multifaceted differences between the CEE and West European estates. The aim of the paper is to analyse the development and rehabilitation challenges that these estates have encountered during post-socialism and thus join the discussion on future prospects and feasible and sustainable upgrading related policies and programmes.
\end{abstract}

Keywords: CEE cities; housing market; large housing estates; prefabricated buildings; rehabilitation policies and programmes, socio-economic composition

\section{INTRODUCTION}

A large or high-density housing estate is defined as a spatially isolated group of buildings comprising at least 2,000 housing units, which has been built during the second half of the $20^{\text {th }}$ century and planned and financed by the state or with state support [1]. Deriving from the postulates of the Athens Charter, it is characterized by multi-family towers and slabs constructed using prefabricated technologies, vast open public spaces, numerous sport fields and playgrounds, abundance of greenery and separation of functions [2].

At the time when they were built, large housing estates in Central and East European (CEE) countries were glorified for quickly and cost-effectively dealing with the housing deficit, while offering relatively good housing conditions [3]. However, low-cost construction and insufficient quality of materials used for prefabricated buildings have generated primarily technical problems that by the end of 1980s manifested themselves through partial physical deterioration and low energy efficiency.

The process of physical downgrading continued during the post-socialist period and was additionally accelerated by neglected or deferred maintenance and dysfunctional system of managing the multi-family housing stock. Since the dwellings located in large housing estates account for almost 50 per cent of the urban housing stock in the CEE region [4], the technical characteristics of their buildings have a substantial influence on the overall housing standard. Due to almost constant housing shortages, as well as to a lower level of residential mobility than in the West European cities, which is not expected to increase considerably in the near future [5], these estates will continue to dominate the local housing markets. Hence, the researches focused on the possibilities for their rehabilitation are of high importance.

Based on relevant literature sources and an interdisciplinary analytical approach, this paper discusses the development of large housing estates in the CEE cities following the fall of communism, with an emphasis on their rehabilitation. It also investigates the causal and complex relationship between the physical state and socioeconomic composition. The research questions concern the issues that have affected their development, mechanisms and methods of coping with them and multifaceted differences between the estates located in the CEE and West European countries in reference to very distinctive socialist and transitional circumstances. The aim of the paper is to analyse the development and rehabilitation challenges that large housing estates have encountered in the course of the post-socialist period and thus contribute to the ongoing debate on future prospects and feasible and sustainable policies and programmes related to their upgrading. The paper first briefly explains their genesis in European cities, then focuses on the post-socialist period, exploring the generators of problems, more or less successful large- and small-scale examples of interventions and general factors that influence the position of these estates on the local housing markets. The last section contains conclusions and recommendations regarding the integrated programmes for their rehabilitation.

\section{HISTORICAL BACKGROUND}

In the times of extensive post-war urbanization, massproduction of prefabricated multi-family buildings, concentrated in high-density housing estates on the outskirts of European cities, turned out to be a very efficient and effective means of resolving the housing crisis. Despite the technical deficiencies that prefabricated technologies bring about, these buildings presented the most suitable solution - their construction was simple, fast and reasonable, it enabled rapid urbanization and kept industrialization as a development priority [6], particularly in the CEE region.

Large housing estates were flourishing on the urban fringes on both sides of the Iron Curtain and had very similar physical features. However, they were characterized by crucial differences from the aspect of socio-economic composition, primarily deriving from the distinctions between the East and the West European model of housing policy [7]. The East European model was 
subordinated to a centralized, party-ruled and planned economic system, and the governments regarded financing, construction and distribution of housing as a matter of politics [8]. The concept of uniform high-density housing fitted perfectly in the socialist ideology that saw urban dwelling as a progressive force encouraging collective rather than individual identity, but also in the egalitarian principles that it cherished [9]. Since reaching equal housing conditions had been set as one of the main objectives of the socialist housing policies, the flats in large housing estates were allocated to the members of the middle class, representatives of the communist party and families of industrial workers. As a result, the socioeconomic composition of these estates in the CEE cities presented a spectrum of various statuses and professions, making social heterogeneity their most distinguishing characteristic [10]. In contrast, the estates in the West European cities were more homogenous, categorized as public housing primarily intended for immigrants and lowincome households [11]. Even though the rigidity of the East European model did create an undifferentiated housing stock, consistent implementation of its principles resulted in a lower level of social discrimination in terms of access to housing than in the West [12].

In the West European cities bleak and repetitive modernist towers and slabs rarely defined the entire residential zone; however, in the CEE cities they were almost the only building type in large housing estates, hence aesthetic plainness that derived from a bland version of Modernism presented their most recognizable feature [13]. Construction of whole neighbourhoods based on unification and multiplication has created an anonymous stock of unmemorable buildings lacking distinctive architectural accents. Additionally, despite the fact that these new neighbourhoods were equipped with public spaces, playgrounds, sport fields and modest social infrastructure, they lacked functional diversity. Their planning concept based on zoning and separation of functions turned them into dormitories.

The trend of construction of high-density housing estates in the West ended relatively quickly, since housing conditions offered by prefabricated technologies have been assessed as quite poor by the 1970s, while in the CEE cities their planning and construction began later and lasted until the end of the 1980s [14]. Notwithstanding the negatives characteristics of these estates, including undifferentiated housing stock, rather low technical standard of prefabricated buildings, monotonous architecture, monofunctionality, spatial anonymity and peripheral location, flats located in them evolved to become the predominant housing type in the CEE region.

\section{POST-SOCIALIST GENERATORS OF PROBLEMS}

The collapse of communism set off systemic political, economic, institutional and social changes that served as catalysts for socio-spatial transformation of the CEE cities and urban landscapes started reflecting their intertwined impact [15]. In terms of the post-socialist development of large housing estates, this meant both status quo and a change.

The post-socialist development trajectory of highdensity housing schemes in the CEE region was first and foremost affected by the institutional and financial issues deriving from the housing policy reform that has been conducted in the early 1990s. Aimed at devising a radically different approach to financing, construction and distribution of flats, thus liberating the state from its previous commitments, the reform involved drastic reduction of state funding, market control of residential construction, state withdrawal from maintenance and repair activities and housing restitution, but most importantly privatization of state or socially owned flats [16].

Combined with housing restitution, privatization had an impressive implementation rate - by 2003, more than 80 per cent of the housing stock in the post-socialist region was in private ownership [17], including almost all flats in large housing estates. It also liberalized the housing market, diversified the housing choices and increased the residential mobility. On the one hand, the process of privatization was successful in terms of reforming the housing sector. On the other hand, even though one of its main goals was to improve residents' attitude towards maintenance of multi-family buildings, it lacked an adequate legislative and institutional framework defining the responsibilities of the new homeowners over the collective parts [18]. The majority of countries have introduced condominium ownership and defined homeowners' associations or condominiums as institutional entities in charge of managing multi-family housing, taking care of finances and initiating renewal projects; yet, the newly established system turned out to be less efficient than anticipated [19]. Weak institutional and financial set-ups, inadequate policies and poor measures of implementation have only aggravated the problem of preserving the socialist housing stock. According to the 'new housing culture', nobody was responsible for taking care of the common parts of multi-family buildings [20].

There were several causes of largely disappointing outcomes in terms of expected residents' active participation in maintenance of the socialist multi-family housing stock [21-23]:

- First, through facilitating the purchase of flats at extremely low prices, in some cases for less than 10 per cent of their real market value (or free of charge in Albania and Moldova), one of the purposes of housing privatization was to quickly absorb the negative social effects of the beginning of the transition. However, privatization conducted in this manner transformed low-income households into homeowners who were unable to cover a share of current operating expenses, let alone a share of costs of repair, new infrastructure and equipment, technical upgrading and partial or full renovation of buildings. Just reducing the consequences of deferred or neglected maintenance required substantial financing, which the homeowners were frequently not willing or able to provide.

- Second, the concept of ownership is not just about the rights and the homeowners were often unaware of their responsibilities towards the common property. Most often, they were opting out of collective actions, making coordinated initiatives challenging. Even when willing to participate in maintaining the collective parts, they were faced with various institutional restraints, unclear 
explanation of their obligations or lack of adequate management and maintenance services.

- Finally, a large percentage of new homeowners did not acknowledge the fact that the value of their flats on the housing markets may significantly drop with worsening of the building's technical state.

The problems that insufficient investments in maintenance, inadequate management of multi-family housing stock, delayed capital repairs and resulting physical downgrading might bring about can have a substantial influence on urban development, since prefabricated buildings dominate the residential landscape of the CEE cities. To illustrate, almost 90 per cent of highrise housing estates in the region were built out of prefabricated components [24]. As an example, flats in prefabricated buildings account for 70 per cent of all housing in Bucharest and 45 per cent in Sofia [25]. The set of possible intertwining issues relates to the following:

- Technical issues [26-28]- In case of extremely poor maintenance, the lifespan of prefabricated buildings is estimated to 50 years. Since the investments in improving their technical condition were frequently lesser than required, a number of these buildings has low energy efficiency compared to the EU standards, poor insulation, outdated infrastructure, damaged facades, leaking roofs, worn out equipment, problems with concrete spalling and mould, etc. Some even display material fatigue and fulfil only basic technical standards.

- Financing issues [29] - The volume of investments in major repairs considerably grows 10 years after construction of prefabricated buildings. As capital investments were often lacking, a not so insignificant share of these buildings has already reached the stage when substantial resources are needed to match contemporary technical standards. In most of the cases, the stream of condominium revenues did not ensure sufficient funds, subsidy programmes were missing, financial responsibilities of the homeowners were not clear enough, while bank loans required audited financial statements, which all-together made financing of technical upgrading rather difficult to manage.

- Issues related to socio-economic transformation-In a situation of more severe physical deterioration of a large housing estate, studies from the 1990s relied on prior West European experience [30-32] foreseeing the following flow of events: 1) middle class out-migration, which would leave ethnic minorities and low-income households behind; 2) increase in unemployment rates and income differentiation on the neighbourhood level; 3) worsening of housing conditions, low quality of life and a significant drop of the flats' market value; 4) overcrowding and poverty; 5) first social, then functional exclusion, in some extreme cases isolation, stigmatization and ghettoization.

- Housing market related issues- Physical and socioeconomic decline of high-density housing schemes would lower the demand for their flats, causing disturbances in the housing markets [33].

- Institutional and financial issues related to maintenance of open public spaces - The structure and spatial distribution of these spaces are inherited from the socialist period, the land is predominantly in public ownership and the responsibility for maintaining them has often been unclear [34].

- Issues related to demographic aging - Owing to a relatively low residential mobility during the post-socialist period, the majority of large housing estates still hosts the original population (couples with children made up a major share of their households during socialism), thus those constructed until the 1980s have a large portion of elderly residents, while those dating from the 1980s are not yet affected by demographic aging [35]. Due to decreasing purchasing power, the pensioners may not be able to meet the housing costs, which can lead to a problem as serious as the inflow of low-income households [36]. The process of demographic aging may cause the age structure of an estate to differentiate, bringing about wider socioeconomic implications. Consequently, it presents one of the most realistic threats to further development of large housing estates in the region.

Not all large housing estates in the CEE cities have been equally affected by or responded in the same manner to mentioned issues. Even though they still look alike and have similar spatial features, these estates are not a homogenous group anymore, as technical quality of the buildings and socio-economic and demographic structure of the population nowadays differ [37]. In reference to their post-socialist development paths, they may be divided into three general types [38]. The first type are the estates that have been regenerated or still display good physical characteristics, feature mixed socio-economic composition, present a relatively desirable housing choice and have favourable development prospects. The second type of the estates has less successfully responded to the post-socialist challenges. It is on the crossroad between regeneration and degradation, meaning that its further development depends on the choice between interventions and a laissez-faire approach. The third type of the estates has the building stock of poor technical quality and mainly hosts low-income households and ethnic minorities. This state resulted from a combination of various issues, such as absence of viable development strategies, inadequate management, insufficient investments in maintenance, constant delay in capital renovations, residents' disinterest in improving the quality of dwelling, etc. The third type is in real risk of physical deterioration and social and decay, thus in urgent need regeneration.

\section{PROGRAMMES AND INITIATIVES RELATED TO REHABILITATION}

The housing policies in the CEE countries have certain differences. However, in comparison to those in the Western Europe, which tackled the problem of large housing estates, the majority of the post-socialist policies provided no clear vision for the role of these estates in the housing markets and, apart from exceptions, it seems that their future development has often been ignored $[39,40]$. Therefore, various attempts to respond to the challenges that many of them encountered (e.g. eliminate or at least reduce the problems caused by neglected maintenance, increase the technical quality of buildings, raise the level of energy efficiency or revitalize open public spaces, etc.) have frequently run into many obstacles, such as financing or lack of long-term and feasible strategies, but the majority primarily relates to the dominance of private 
ownership. 'Giveaway' privatization became the delineating feature of the post-socialist housing systems, denoting withdraw of the state [41]. Hence, in circumstances where the rights, preferences and finances of the homeowners need to be taken into account, a rehabilitation should be based on effective cooperation between all stakeholders - city government, relevant public institutions, private investors and local population, with the aim of reaching consensus on actions and making decisions from which all of them would benefit [42].

In terms of the programmes for regeneration of housing estates in the CEE countries, especially from the aspect of addressing the issue of private ownership, the examples of good practice can be found in Czech Republic, where they were managed and subsidized under national or local policies. Owing to a well-designed and coordinated initiative, JižníMěsto (South Town), the biggest socialist housing scheme in Prague, underwent a process of extensive physical upgrading [see 43]. The city council has independently financed revitalization of social housing and public spaces, while the public officials have motivated the homeowners to cover a share of expenses for renovation of their buildings and undertake joint revitalization activities. The project resulted not only in raised technical quality of prefabricated buildings, but also in raised quality of life, making JižníMěsto both appealing and affordable location, especially for couples with children, which contributed to preserving the social mix and slowing down the process of demographic aging. Yet, due to low levels of socio-spatial disparity in Prague, policies aimed at large regeneration projects are not the city's top priority anymore and changes in the socialist housing estates are nowadays market-driven [44].

There are also cases when the policies did recognize the future development of large housing estates, yet the regeneration programmes gave mixed results. In order to be successful, these programmes need to anticipate the impact of a whole range of factors, such as housing supply and demand, influence of other policies, socio-economic and demographic structure of the estate, especially in terms of their interaction. Attributable to several overlooked factors, the programmes for improving the quality of prefabricated buildings in high-density housing schemes in East Berlin, for example, did not meet the initial expectations. This was caused by an error in the approach - a highly centralized top-down initiative was not accompanied by necessary analyses of the housing market needs and appropriate policy on residential decentralization [see 45]. The programmes did ensure active, primarily financial participation of the homeowners and by 2003 , over 60 per cent of the socialist housing stock has been completely renovated. On the other hand, increase in prices of renovated flats has produced relatively high vacancy rates and initiated suburbanization. However, large housing demand has reinforced the position of these estates in the local market.

In comparison with less radical CEE policies related to renewal of large housing estates, in many West European cities they proposed an approach involving selective demolition in cases of over-supply (or under-demand) of flats, usually in more problematic estates [46]. It encompasses a set of integrated measures and interventions, more specifically refurbishment of buildings, renovation of flats, development of new functions and many tasks concerning social, economic and safety improvements, with the aim of upgrading the estates both socially and physically [47]. For example, this approach was applied to Bijlmermeer, the Netherlands' most well-known high-density housing estate located in Amsterdam' suburbia, which has already entered the spiral of decline (e.g. bad image, severe physical deterioration, social decay, low quality of life, middle class outmigrations and high vacancies) and over-supplied a very 'tight' housing market [see 48]. The project involved refurbishment of 75 per cent of dwellings intended for middle to higher income households and demolition of remaining 7,000 dwellings, followed by construction of low- to medium-rise housing and new recreational, cultural, leisure and social welfare facilities. It was accompanied by various methods of social enhancements, e.g. the unemployed residents were engaged in construction of new buildings, migrants were taught Dutch language, etc. The progress of renewal has been assessed with an instrument called 'Bijlmermonitor', first annually then biannually. This approach is less common for the postsocialist cities, since the flats in their large housing estates are constantly in high demand, yet a wholesale demolition has recently been announced in Moscow [see 49]. Up to 7,900 'Khrushchevka' prefabricated buildings are set to be torn down and replaced by housing towers, causing relocation of 1.6 million people.

In contrast to these large-scale regeneration programmes that required considerable investments, there are examples of successful rehabilitation initiatives on a smaller scale, which were also aimed at creating a responsible local community. To illustrate, the government of Tallinn developed several upgrading programmes for the homeowners' associations to apply for funding or cofunding, such as 'Repair the facades' for making the buildings more energy efficient and 'Tidy up the yard' for supporting the renewal of public spaces between buildings [50]. At the same time, there are examples of non-strategy based ad hoc private initiatives from the CEE cities in which regeneration of high-density housing estates is not recognized by the policies, as in case of scattered construction of rooftop housing extensions to prefabricated buildings in Serbian cities. It was led by small private investors who compensated the homeowners in repaired roofs, repainted corridors and facades, added balconies or new elevators. Yet, as they did not finance major renewal of infrastructure, improvement of energy efficiency or revitalization of open public spaces, the technical quality of the buildings or the dwelling quality have not been significantly affected.

Many post-socialist policies related to improving the physical quality of large housing estates relied on those implemented in the West during the 1980s, which predominantly dealt with the scale of buildings, devising their modernization and technical renewal focused on energy saving, and overlooked the neighbourhood scale [51]. This mainly refers to the lack of more integrated approaches that involve revitalization of open public spaces, introduction of new amenities and measures devised to enhance the relationship between the neighbourhood and the city. In addition, better results may be achieved by incorporating funds for renovation of flats, 
since the homeowners would then have a much greater interest in protecting the investment within a broader context of upgraded building and neighbourhood [52]. The fact that the market value of their flats would considerably increase if the conditions on all three scales - flat, building and neighbourhood - improve might influence residents' motivation and willingness to participate in rehabilitation programmes by investing their time and sharing the regeneration costs.

\section{$5 \quad$ POSITION IN THE HOUSING MARKET}

As the typology of high-density housing estates in the CEE cities has depicted, some of them currently display mild or more serious signs of physical deterioration, worsening of housing conditions, socio-economic decay and demographic aging. Yet, the studies have showed that, in comparison to their counterparts in the West European cities, they are less likely to enter the spiral of decline, i.e. the process of serious, progressive and multi-layered physical and socio-economic downgrading $[53,54]$. The reasons for this are linked with the general factors that influence the future of these estates and their position in the local housing markets, especially of those that have been rehabilitated, which are as follows [55,56]:

- As the share of flats located in high-density housing estates is immense, they will probably continue to be the most dominant housing type in the CEE cities.

- Due to lower incomes, less diversified housing offer and consequent more modest housing aspirations of the CEE citizens, the level of residential mobility in the postsocialist cities is lower than in the West, meaning that the majority of households will probably decide not to move out from large housing schemes. In addition, the flats located in them are frequently the cheapest in the local housing markets [57].

- This decision is reinforced by the fact that housing privatization converted long-time tenants to homeowners, thereby strengthening their emotional bond with the flat and attachment to the neighbourhood.

- Despite some studies from the 1990s, which forecasted extensive middle class out-migrations, a large share of high-density housing estates still has mixed socioeconomic composition.

- The counter-balance in demographic aging usually happens in the estates that offer good housing conditions at affordable prices and attract young people and couples with children, thus serving as housing market 'springboards', or in the estates in the proximity of university campuses, which are becoming prime rental locations for students [58].

Additionally, the majority of large housing estates no longer act as isolated mono-functional dormitories. They are nowadays equipped with commercial facilities, have developed social infrastructure and improved transport connections, and provide access to various services. In some cases, they are even characterized by certain benefits compared to some new inner-city neighbourhoods. To illustrate, the survey of residents' satisfaction conducted in a centrally located and newly built multi-family housing estate in Novi Sad, Serbia, showed that out of 42 per cent of the respondents willing to move out, more than half would choose living in socialist housing schemes [59]. As their advantages, the respondents stated the following: planned bicycle paths, transport accessibility, more playgrounds, sport fields, greenery and public spaces, and less noise, traffic and parking issues.

Another influential factor refers to the level of residents' satisfaction, i.e. the attitude of the residents towards living in the estate, which varies according to studies. In Croatian cities, for example, albeit some signs of social and physical degradation, large housing estates are not categorized as problematic - they maintain the inherited socio-economic mix, offer relatively good housing conditions and still present a dwelling location that is appealing to the middle class [60]. In Sofia, dwelling in the socialist estates is not considered as the first choice, but seems to be well-accepted by the residents; in Vilnius, these estates are lacking the upgrading potential because of their peripheral location and physical state, yet they still feature high social stability and have a moderately high level of households' satisfaction [61]. The situation in Polish large housing estates is somewhat different. Even though several sociological researches show that the quality of dwelling they offer is generally decent, the majority of the residents do not consider them as a good place to live [62]. In Budapest, some socialist housing estates have a negative reputation and display symptoms of socio-economic decline, while some are exceptionally popular in the housing market, attracting younger and more affluent social strata [63]. In general terms, the majority of high-density housing estates in the CEE cities still feature mixed socio-economic compositions, have a moderately good image, offer relatively favourable dwelling conditions and a large share of the residents perceive them as a relatively good dwelling option [64]. The variations in the level of residents' satisfaction between the estates within a same city derive from the differences in physical condition of the buildings, socio-economic structure of households, quality of open public space, safety, etc. The variations between the cities additionally derive from the differences in housing policies, but also from the type of housing market. High-density housing schemes will remain less popular and have more unsatisfied or 'trapped' households in 'relaxed' markets with diversified housing choices, while they will remain attractive and have more satisfied households in 'tight' markets, in which housing supply is dominated by prefabricated buildings and the choices are limited [65].

Owing to a combination of mentioned influential factors, the position of socialist high-density estates in the housing markets of the CEE cities will most probably continue to be stable. However, possible enlargement of the housing stock and consequent diversification of the housing preferences and choices might endanger the stability, again emphasizing the importance of their rehabilitation.

\section{CONCLUSION AND RECOMMENDATIONS}

The West European experience with large housing estates on urban fringes drew attention to severe and longterm socio-economic problems caused by deterioration of their building stock. In spite of quite dramatic predictions, more recent studies indicate that the image of these estates in the $\mathrm{CEE}$ cities is less negative and that they are not 
inevitably following the path of physical and socioeconomic decline almost typical for their counterparts in the West, primarily due to the joint impact of various transitional processes. However, in order to prevent more serious physical and socio-economic degradation from happening, creation of feasible rehabilitation related policies and programmes with more integral approaches needs to be listed among the priorities of urban development in the CEE region. Apart from avoiding numerous social and financial costs of downgrading, the necessity for their creation also derives from a crucial role these estates have in functioning of the local housing markets due to the share of their flats in the total housing stock.

As previously stated, large housing estates in the CEE cities have similar characteristics from the aspect of physiognomy, but in contrast to the socialist period, their technical characteristics and socio-economic compositions nowadays differ. Consequently, there is no universal rehabilitation programme that guarantees exclusively positive results. In addition, these estates require different policy treatment in more prospering service-oriented cities, where population is constantly increasing, and in former industrial towns, where population shrinkage is almost irreversible [66], which points out to a wider context of factors, e.g. geo-political situation, economic and demographic changes, housing policy, supply and demand in the local housing market, etc. Therefore, every regeneration initiative requires an interdisciplinary and holistic approach to detecting and analysing concrete problems and challenges in each individual case. This is followed by choosing sustainable and both socially and financially viable methods of technical intervention for the building scale, ranging from repair and renovation, over partial or total reconstruction to demolition, and for the scale of flats and neighbourhood, with the aim of not just upgrading the buildings, but improving the overall physical and social quality of the estate.

Successfulness of rehabilitation programmes also depends on active involvement of all stakeholders, while effective and efficient residents' participation presents a key determinant. In order to ensure it, the issues regarding the financial and institutional framework for maintaining and managing the multi-family housing stock in the circumstances of dominant private ownership need to be addressed. Therefore, policies and programmes related to rehabilitation of large housing estates should consider the rights and obligations of the homeowners, yet based on a realistic evaluation of their financial capabilities. With reference to current socio-economic situation in the CEE region, the level of participation relies on provision of systemic measures of financial support, such as statesubsidies, low interest rate loans, discounts, incentives, refunds, tax deductions, public-private partnerships, etc. In addition, since the homeowners who perceive their neighbourhood as a good place to live are far more likely to initiate and participate in do-it-yourself activities in maintenance [67], reaching a higher dwelling quality in large housing estates may also provide benefits in terms of residents' attitude towards further maintenance and their motivation to preserve the upgraded living environment. In relation to this, some researches emphasize the role of sense of community, neighbourhood attachment, collective efficiency [68] and social capital in the rehabilitation process [69].

Adoption of policies, long-term development strategies and feasible programmes for technical upgrading and regeneration of high-density housing estates has been set as one of the challenges of developing the European city of the future [see 70]. The challenge is greater in the CEE region than in the West, as these estates provide home for a quite large share of its urban population. Furthermore, almost 15 years have passed since the RESTATE project (Restructuring Large-scale Housing Estates in European Cities - practices and new visions for sustainable neighbourhoods and cities, a FP5 EU funded Project 2002-2005) produced in-depth studies of 29 European estates, describing good evidence-based upgrading practices. Therefore, thorough analyses of possible methods for rehabilitation of these estates in the CEE cities, especially in 'relaxed' housing markets where various processes that may transform their socio-economic and demographic structure and cause wider consequences on the city level have already started, present a highly complex, yet important topic for future interdisciplinary researches.

\section{Acknowledgements}

The paper was done within the projectsNo.TR36042 and 179037, funded by the Ministry of Education and Science, Republic of Serbia, and project No. 114-4512790/2016-01, financed by the Provincial Secretariat for Higher Education and Scientific Research, Republic of Serbia.

\section{REFERENCES}

[1] Murie, A., van Kempen, R., \& Knorr-Siedow, T. (2003). Large Housing Estates in Europe, General Developments and Theoretical Background-RESTATE Report. Utrecht: Faculty of Geosciences, Utrecht University.

[2] Musterd, S. \& van Kempen, R. (2005). Large-scale housing estates in European cities: Opinions of residents on recent developments - RESTATE Report. Utrecht: Faculty of Geosciences, Utrecht University.

[3] Dekker, K., Hall, S., van Kempen, R., \&Tosics, I. (2005). Restructuring large housing estates in European cities: An introduction. In R. van Kempen, K. Dekker, S. Hall \& I. Tosics (Eds), Restructuring large housing estates in Europe (pp. 1-17). Bristol: University of Bristol. https://doi.org/10.1332/policypress/9781861347756.003.0001

[4] Grossmann, K., Kabisch, N., \& Kabisch, S. (2017). Understanding the social development of a post-socialist large housing estate: The case of Leipzig-Grunau in eastern Germany in long-term perspective. European Urban and Regional Studies, 24(2), 142-161. https://doi.org/10.1177/0969776415606492

[5] Herfert, G., Neugebauer, C. S., \& Smigiel, C. (2013). Living in residential satisfaction? Insights from large-scale housing estates in Central and Eastern Europe. Tijdschrift voor Economische en Sociale Geografie, 104(1), 57-74. https://doi.org/10.1111/j.1467-9663.2012.00727.x

[6] Smith, D. (1996). The Socialist City. In G. Andrusz, M. Harloe\& I. Szelenyi (Eds), Cities after socialism - urban and regional change and conflict in post-socialist societies (pp. 70-99). Cambridge \& Oxford: Blackwell Publishing.

[7] Hegedüs, J. \& Tosics, I. (1997). Transition from the EastEuropean Housing Model - Heading to Where? In H. 
Vestergaard (Ed), Housing in Europe (pp. 57-77). Horsholm: Danish Building Research Institute.

[8] Tosics, I. (2005). City development in Central and Eastern Europe since 1990: The impact of internal forces. In F. E. I. Hamilton, K. Dimitrovska Andrews \& N. Pichler-Milanovic (Eds), Transformation of Cities in Central and Eastern Europe: Towards Globalization (pp. 44-78). Tokyo: United Nations University Press.

[9] Smith (1996).

[10] Ouředníčeka, M. \&Temelová, J. (2009). Twenty Years after Socialism: The Transformation of Prague's Inner Structure. Studia Universitatis Babeş-Bolyai, 54(1), 9-30. Retrieved from: http://www.studia.ubbcluj.ro/download/pdf/429.pdf

[11] Friedrichs, J., Galster, G., \& Musterd, S. (2003). Neighborhood effects on social opportunities: The European and American research and policy context. Housing Studies, 18(6), 797-806. https://doi.org/10.1080/0267303032000156291

[12] Szelenyi, I. (1983). Urban Social Inequalities under State Socialism. Oxford \& New York: Oxford University Press.

[13] Hirt, S. (2006). Post-Socialist Urban Forms: Notes from Sofia. Urban Geography, 27(5), 464-488. https://doi.org/10.2747/0272-3638.27.5.464

[14] Dimitrovska Andrews, K. \& Sendi, R. (2001). Large Housing Estates in Slovenia: A Framework for Renewal. European Journal of Housing Policy, 1(2), 233-255. https://doi.org/10.1080/14616710110083443

[15] Nedučin, D. \& Krklješ, M. (2017). Post-socialism and urban transition: Transforming the socialist city. Facta Universitatis - Series: Architecture and Civil Engineering, 15(3), 347-357. https://doi.org/10.2298/FUACE160817023N

[16] Struyk, R. (1996). Housing privatization in the former Soviet block to 1995. In G. Andruzs, M. Harloe \& I. Szelenyi (Eds), Cities after Socialism: Urban and Regional Change and Conflict in Post-Socialist Societies (pp. 192-213). Oxford \& Cambridge: Blackwell Publishing Ltd. https://doi.org/10.1002/9780470712733.ch6

[17] European Foundation for the Improvement of Living and Working Conditions (2004). Quality of life in Europe - First European Quality of Life Survey 2003. Luxembourg: Office for Official Publications of the European Communities.

[18] ECE (2003). Guidelines on Condominium Ownership of Housing for Countries in Transition. New York \& Geneva: Economic Commission for Europe \& United Nations.

[19] Gruis, V., Tsenkova, S. \&Nieboer, N. (2009). Introduction. In V. Gruis, S. Tsenkova\& N. Nieboer (Eds), Management of Privatized Housing: International Policies \& Practice (pp. 1-18). Oxford \& Chichester: Wiley-Blackwell. https://doi.org/10.1002/9781444322613.ch1

[20] Damjanović, D. \& Gligorijević, Ž. (2010). Socijalno stanovanje: Prikaz stambenih politika Srbije $i$ odabranih zemalja Evrope. Belgrade: Palgocentar.

[21] Tsenkova, S. (2005) Trends and progress in housing reforms in southeast Europe. Paris: Council of Europe Development Bank.

[22] Cirman, A., Mandič, S., \& Zorić, J. (2013). Decisions to Renovate: Identifying Key Determinants in Central and Eastern European Post-socialist Countries. Urban Studies, 50(16), 3378-3393. https://doi.org/10.1177/0042098013482509

[23] Soaita, A. M. (2012). Strategies for In Situ Home Improvement in Romanian Large Housing Estates. Housing Studies, 27(7), 1008-1030. https://doi.org/10.1080/02673037.2012.725833

[24] Tsenkova, S. \& French, M. (2011). Affordable land and housing in Europe and North America. Nairobi: UNHABITAT.

[25] Tsenkova, S. (2014). The housing policy nexus and people's responses to housing challenges in post-communist cities. Urbani Izziv, 25(2), 90-106. https://doi.org/10.5379/urbani-izziv-en-2014-25-02-002

[26] Tsenkova, S. (2009). Housing Policy Reforms in Post Socialist Europe - Lost in Transition. Heidelberg: PhysicaVerlag, Springer. https://doi.org/10.1007/978-3-7908-2115-4

[27] Jovanović Popović, M., Ignjatović, D., Radivojević, A., Rajčić, A., Đukanović, Lj., Ćuković Ignjatović, N., \& Nedić, M. (2013). Atlas of Multifamily Housing in Serbia. Belgrade: University of Belgrade.

[28] Mrówczyńska, M., Łączak, A., Bazan-Krzywoszańska, A., \& Skiba, M. (2018). Improving Energy Efficiency with the Risk of Investment of Reference to Urban Development of ZielonaGóra. Technical Gazette, 23(5), 916-922. https://doi.org/10.17559/TV-20161212120336

[29] Tsenkova (2009).

[30] Maier, K. (1997). Problems of housing estates and the case of Prague. In Z. Kovács \& R. Wiessner (Eds), Prozesse und Perspektiven der Stadtentwicklung in Ostmitteleuropa (pp. 231-243). Passau: L. I. S. Verlag.

[31] Egedy, T. (2000). The situation of high-rise housing estates in Hungary. In Z. Kovács (Ed), Hungary towards the $21^{\text {st }}$ Century: The Human Geography of Transition (pp. 169185). Budapest: Geographical Research Institute.

[32] Kovács Z. (1999). Cities from state-socialism to global capitalism: An introduction. Geo Journal, 49(1), 1-6. https://doi.org/10.1023/A:1007048819606

[33] Dekker, K. \& van Kempen, R. (2004). Large Housing Estates in Europe: Current Situation and Developments. Tijdschrift voor Economische en Sociale Geografie, 95(5), 570-577. https://doi.org/10.1111/j.0040-747X.2004.00340.x

[34] Benkő, M., Balla, R., \& Hory, G. (2018). Participatory placemaking in the renewal of post-communist large prefabricated housing estate: Újpalota case study, Budapest. Journal of Place Management and Development, 11(2), 223-241. https://doi.org/10.1108/JPMD-06-2017-0050

[35] Gorczyca, K. (2016). The social transformation of large housing estates in Poland at the turn of the $21^{\text {st }}$ century. Czech Sociological Review, 52(6), 861-892. https://doi.org/10.13060/00380288.2016.52.6.289

[36] Temelová, J. \& Slezáková, A. (2014). The changing environment and neighbourhood satisfaction in socialist high-rise panelhousing estates: The time-comparative perceptions of elderly residents in Prague. Cities, 37(2014), 82-91. https://doi.org/10.1016/j.cities.2013.12.002

[37] Musterd, S. \& van Kempen, R. (2007). Trapped or on the springboard? Housing careers in large housing estates in European cities. Journal of Urban Affairs, 29(3), 311-329. https://doi.org/10.1111/j.1467-9906.2007.00345.x

[38] Temelová, J., Novák, J., Ouředniček, M., \& Puldová P. (2011). Housing Estates in the Czech Republic after Socialism: Various Trajectories and Inner Differentiation. Urban Studies, 49(9), 1811-1834. https://doi.org/10.1177/0042098010379279

[39] Murie, A. \& van Kempen, R. (2009). Large Housing Estates, Policy Interventions and the Implications for Policy Transfer. In R. Rowlands, S. Musterd \& R. van Kempen (Eds), Mass Housing in Europe - Multiple Faces of Development, Change and Response (pp. 191-212). Basingstoke: Palgrave Macmillan. https://doi.org/10.1057/9780230274723_8

[40] Leetmaa, K., Holvandus, J., Mägi, K., \& Kährik, A. (2018). Population Shifts and Urban Policies in Housing Estates of Tallinn, Estonia. In D. Hess, T. Tammaru\& M. van Ham (Eds), Housing Estates in Europe - Poverty, Ethnic Segregation and Policy Challenges (pp. 389-412). Cham: Springer. https://doi.org/10.1007/978-3-319-92813-5_17

[41] Stephens, M., Lux, M., \& Sunega, P. (2016). Post-Socialist Housing Systems in Europe: Housing Welfare Regimes by Default? Housing Studies, 30(8), 1210-1234. https://doi.org/10.1080/02673037.2015.1013090 
[42] Trumbull, N. S. (2014). Restructuring socialist housing estates and its impact on residents' perceptions: 'Renovatsiia' of khrushchevki in St. Petersburg. GeoJournal, 79(4), 495-511. https://doi.org/10.1007/s10708-014-9534-1

[43] Temelová et al. (2011).

[44] Ouředníček, M., Špačková, P., \& Pospíšilová, L. (2018). Long-term Development and Current Socio-Spatial Differentiation of Housing Estates in Prague. In D. Hess, T. Tammaru\& M. van Ham (Eds), Housing Estates in Europe Poverty, Ethnic Segregation and Policy Challenges (pp. 339360). Cham: Springer. https://doi.org/10.1007/978-3-319-92813-5_15

[45] Stanilov, K. (2007). Housing Trends in Central and Eastern European Cities During and After the Period of Transition. In K. Stanilov (Ed), The Post-Socialist City: Urban Forms and Space Transformation in Central and Eastern Europe after Socialism (pp. 173-190). Dordrecht: Springer. https://doi.org/10.1007/978-1-4020-6053-3_9

[46] Wassenberg, F. (2012). Housing Estates. In S. J. Smith (Ed). International Encyclopaedia of Housing and Home (pp. 444449). Heidelberg: Elsevier Science. https://doi.org/10.1016/B978-0-08-047163-1.00530-0

[47] Hess, D. B., Tammaru, T., \& van Ham, M. (2018). Lessons Learned from a Pan-European Study of Large Housing Estates: Origin, Trajectories of Change and Future Prospects. In D. Hess, T. Tammaru \& M. van Ham (Eds), Housing Estates in Europe - Poverty, Ethnic Segregation and Policy Challenges (pp. 3-34). Cham: Springer. https://doi.org/10.1007/978-3-319-92813-5

[48] Wassenberg, F. (2013). Large housing estates: Ideas, rise, fall and recovery - The Bijlmermeer and beyond. Delft: Delft University of Technology.

[49] Luhn, A. (2017, March 31). Moscow's big move: is this the biggest urban demolition project ever? Guardian. Retrieved from:https://www.theguardian.com/cities $/ 2017 / \mathrm{mar} / 31 / \mathrm{mos}$ cow-biggest-urban-demolition-project-khrushchevka-flats

[50] Leetmaa et al. (2018).

[51] Muliuolyte, J. (2013). Rediscovering large-scale housing estates in post-socialist cities. Journal of Architecture and Urbanism, 37(1), 51-58. https://doi.org/10.3846/20297955.2013.781180

[52] Milstead, T. M. \& Miles, R. (2011). DIY Home Improvements in a Post-Soviet Housing Market: A SocioSpatial Analysis of Vilnius, Lithuania. Housing Studies, 26(3), 403-421. https://doi.org/10.1080/02673037.2011.542099

[53] Kabisch, S. \& Grossmann, K. (2013). Challenges for large housing estates in light of population decline and ageing: Results of a long-term survey in East Germany. Habitat International, 39(2013), 232-239. https://doi.org/10.1016/j.habitatint.2012.12.003

[54] Skřivánková, L., Švácha, R., Novotná, E., \& Jirkalová, K. (2017). The Paneláks: twenty-five housing estates in the Czech Republic. Prague: Museum of Decorative Arts.

[55] Szafrańska, E. (2014). Transformations of large housing estates in post-sociality city: The Case of Łódź, Poland. Geographia Polonica, 87(1), 77-93. https://doi.org/10.7163/GPol.2014.5

[56] Szafrańska, E. (2015). Transformations of large housing estates in Central and Eastern Europe after the collapse of communism. Geographia Polonica, 88(4), 621-648. https://doi.org/10.7163/GPol.0037

[57] Ouředníček, M. (2016). The relevance of "Western" theoretical concepts for investigations of the margins of postsocialist cities: the case of Prague. Eurasian Geography and Economics, 57(4-5), 545-564. https://doi.org/10.1080/15387216.2016.1256786

[58] Kovács, Z. \& Herfert, G. (2012). Development pathways of large housing estates in post-socialist cities: An international comparison. Housing Studies, 27(3), 324-342. https://doi.org/10.1080/02673037.2012.651105

[59] Nedučin, D. (2014). Post socijalistički grad - promena društvene $i$ prostorne structure Novog Sada u period tranzicije. Unpublished $\mathrm{PhD}$ dissertation done at the Faculty of Technical Sciences, University of Novi Sad, Serbia.

[60] Spevec, D. \& Klempic, B. (2009). Croatian cities under transformation: New tendencies in housing and segregation. Tijdschrift voor Economische en Sociale Geografie, 100(4), 454-468. https://doi.org/10.1111/j.1467-9663.2009.00552.x

[61] Brade, I., Herfert, G., \& Wiest, K. (2009). Recent Trends and Future Prospects of Socio-Spatial Differentiation in Urban Regions of Central and Eastern Europe: A lull before the storm? Cities, 26(5), 233-244. https://doi.org/10.1016/j.cities.2009.05.001

[62] Klima, E., Janiszewska, A., Grabski, L., \& Woldendorp, T. (2016). Improving the quality of life with CPTED methodology: High-rise housing in Widzew, Łódź. Journal of Place Management and Development, 9(2), 210-223. https://doi.org/10.1108/JPMD-09-2015-0032

[63] Kovács, Z., Egedy, T., \& Szabó, B. (2018). Persistence or Change: Divergent Trajectories of Large Housing Estates in Budapest, Hungary. In D. Hess, T. Tammaru\& M. van Ham (Eds), Housing Estates in Europe - Poverty, Ethnic Segregation and Policy Challenges (pp. 191-214). Cham: Springer. https://doi.org/10.1007/978-3-319-92813-5_9

[64] Dekker, K., de Vos, S., Musterd, S., \& van Kempen, R. (2011). Residential Satisfaction in Housing Estates in European Cities: A Multi-level Research Approach. Housing Studies, 26(4), 479-499. https://doi.org/10.1080/02673037.2011.559751

[65] Kovács \& Herfert (2012).

[66] Benkő, M. (2015). Budapest's Large Prefab Housing Estates: Urban Values of Yesterday, Today and Tomorrow. Hungarian Studies, 29(1-2), 21-36. https://doi.org/10.1556/044.2015.29.1-2.2

[67] Milstead \& Miles (2011).

[68] Walton, E. (2016). It's Not Just a Bunch of Buildings: Social Psychological Investment, Sense of Community, and Collective Efficacy in a Multiethnic Low-Income Neighborhood. City \& Community, 15(3), 231-263. https://doi.org/10.1111/cico.12189

[69] Scottish Government (2017). Review of the community-led regeneration approach as delivered via the People and Communities Fund - People, community and places. Edinburg: Scottish Government.

[70] EC (2011). Cities of Tomorrow - Challenges, Visions, Ways Forward. Brussels: European Commission.

\section{Contact information}

Dejana NEDUČIN, PhD, Assistant Professor University of Novi Sad, Faculty of Technical Sciences, Department of Architecture and Urban Planning, Trg Dositeja Obradovića 6, 21000 Novi Sad, Serbia d.neducin@uns.ac.rs

Marko ŠKORIĆ, PhD, Associate Professor University of Novi Sad, Faculty of Philosophy, Department of Sociology,

Dr Zorana Đinđića 2, 21000 Novi Sad, Serbia mskoric@ff.uns.ac.rs

Milena KRKLJEŠ, PhD, Associate Professo University of Novi Sad, Faculty of Technical Sciences Department of Architecture and Urban Planning, Trg Dositeja Obradovića 6, 21000 Novi Sad, Serbia mkrkljes@uns.ac.rs 